\title{
Teamarbejdets dannelsesdynamikker og spændingsforhold - belyst og diskuteret med afsæt i en dansk virksomhedsorganisation
}

\section{Maja Marie Lotz \& Signe Enemark Olsen}

Artiklen er baseret på et kvalitativt casestudie om fællesskabets betydning for medarbejdernes udvikling og dannelse på jobbet. Artiklen belyser og diskuterer i et dannelsesperspektiv, hvorledes nutidens teamdynamikker og spændingsforhold føles på kroppen og under huden på produktionsmedarbejdere og akademikere i casevirksomheden Bildung A/S - og hvilke skyggesider et teamfællesskab i en stærk værdibaseret virksomhedskultur også kan have. Artiklen forsøger at medtænke såvel de positive dimensioner som de negative konsekvenser af arbejdslivets aktuelle socialitetsformer og teamorganiseringens udviklingstendenser.

\section{Indledning}
$\mathrm{A}$
$t$ teamtankegangen og teamspirit jargo-
nen i dag ikke længere blot har sporten som sin hjemmebane, men også præger li- vet på mange af nutidens arbejdspladser, er en interessant fusion - ikke mindst i lyset af nutidens udbredte 'individualiseringsiver'. For hvorfor sætte fokus på fællesskab, team- relationer og de sociale bånd $\mathrm{i}$ arbejdslivet $\mathrm{i}$ en tid, som oftest karakteriseres med begre- ber som individualisering, selvrealisering og fragmentering, og hvor vores forbilleder først og fremmest er personlig frihed, uaf- hængighed, eget initiativ og selvudvikling? Også i arbejdslivet sætter disse forbilleder og tendenser sig igennem. Netop arbejdet er i dag i de fleste menneskers liv en vital kilde til selvidentitet og selvdannelse og arbejds- pladsen et personligt 'væksthus' for vores stræben efter selvrealisering, selvbestem- melse, selvudfoldelse og selvudvikling mv.

Umiddelbart synes teamarbejdsformen og dens fællesskabsånd ikke at matche vores iver efter selvrealisering, men spørgsmålet er, om måden, vi former os selv og vores liv på, udelukkende er karakteriseret af sådanne radikale individualiseringstendenser uden rum for fællesskaber og tætte sociale bånd? Eller om der i takt med individualiseringen skabes nye former for fællesskab og socialitet - som måske snarere er en forudsætning for vores frihed og selvrealisering? Teamet og nutidens kollektive praksissammenhænge på jobbet kunne være et bud herpå. Hensigten med denne artikel er at udforske denne tematik på baggrund af et kvalitativt casestudie på virksomheden Bildung A/S (B A/S), der i et dannelsesperspektiv sætter fokus på samspillet mellem selvrealisering og fællesskab blandt medarbejderne. ${ }^{1}$ Undersøgelsen illustrerer empirisk, at disse to dannelsesdimensioner er gensi- 
digt betingede, og at fællesskabsformerne i arbejdslivet (som f.eks. teamet) er en forudsætning for medarbejdernes selvrealisering. I dette lys er dannelse ikke et 'one man show', men en social proces, der altid udfolder sig i kraft af et samspil mellem de to dimensioner: selvrealisering og fællesskab. En genuin forståelse af de dannelsesformer og -dynamikker, der er på spil blandt medarbejderne i nutidens arbejdsliv, kræver derfor, at arbejdspladsens former for socialitet medtænkes og udforskes. Netop teamarbejdsformens 'natur' kan siges at aktualisere et øget fokus på de sociale relationer og fællesskabet mellem medarbejderne. Men mens der inden for den eksisterende teamlitteratur er undersøgt og skrevet meget om, hvordan teams konkret er opbygget og fungerer, hvordan de ledes, og hvorledes teamarbejdsformen ofte går hånd i hånd med fleksibilitet, medarbejderudvikling, kontinuerlig læring, 'frihed under ansvar', øget medarbejderinddragelse, beslutningskompetence mv. (Hvenegaard 2003; Csonka 2000), er teamets socialitetsformer og rum for fællesskabsdannelser et mere underbelyst felt.

Nærværende artikel søger at kaste lys over dette 'videnshul', idet vi med udgangspunkt i vores undersøgelse vil diskutere fællesskabets betydning for medarbejdernes udvikling og dannelse på jobbet samt de skyggesider, som et dynamisk teamfællesskab og en stærk fælles virksomhedskultur ligeledes aktualiserer. Artiklen anlægger et gennemgående komparativt perspektiv på, hvorledes hhv. produktionsmedarbejderne og akademikerne i B A/S erfarer og gør brug af virksomhedens teambaserede måder at lede og arbejde på - og på de rum for fællesskab, der udspringer heraf. I det følgende vil vi først præsentere undersøgelsens case og metode. Dernæst vil vi skitsere den analytiske ramme, hvormed vi har forsøgt at indfange og begribe fællesskabernes liv og betydning i B A/S. Efter denne introduktion til de anvendte grundbegreber og dannelsesperspektivet vil vi rette blikket mod $\mathrm{B} \mathrm{A} / \mathrm{S}^{\prime}$ teambaserede arbejdstakt og selskabelige omgangstone, hvordan den subjektivt opleves, samt hvilke dannelsesdynamikker og spændingsforhold som virksomhedens teamorganisering og øvrige socialitetsformer giver anledning til blandt medarbejderne.

\section{Metode og introduktion til undersøgelsens case}

Når vi sætter fokus på den subjektive oplevelse af samspillet mellem selvrealisering og fællesskab i nutidens arbejdsliv, synes det kvalitative casestudie at være et ideelt redskab. Casestudiet lægger op til et multimetodologisk approach, og konkret tager vores undersøgelse udgangspunkt i et sæt af metodiske redskaber, der omfatter kvalitative individuelle interview, fokusgruppeinterview, observation og deltagerobservation, tekstanalyse samt et fotoprojekt. Sigtet med disse supplerende metodiske tilgange har været at inddrage forskellige opfattelser af og erfaringer med teamarbejdet og dermed tydeliggøre de subjektive betydningsdimensioner, som medarbejderne tillægger arbejdet og de dannelsesdynamikker og spændingsforhold, som udspringer af den teambaserede arbejdsform. ${ }^{2}$ I artiklen vil det dog primært være citater fra undersøgelsens interviewmateriale, der vil blive inddraget, om end de øvrige metodiske tilgange naturligvis også er medkonstituerende for vores analytiske blik og konklusioner (Stake 1998). Endvidere betragter vi de individuelle interview og vores fokusgruppeinterview som ligestillede former for dataproduktion, og de to interviewformer bruges derfor som ligeværdige kilder i analysen (Halkier 2002).

Vores valg af den danske medicinalvirksomhed med synonymet Bildung A/S, som undersøgelsens case, skyldes dels, at virksomheden, der har omkring 2000 ansatte, 
er i front med hensyn til fleksibel ledelse, nye teambaserede arbejdsformer, livslang læring og udviklingen af en værdibaseret virksomhedskultur og dels, at de både beskæftiger akademikere og produktionsmedarbejdere. ${ }^{3}$

Grundstammen i undersøgelsens empiri består af det kvalitative interviewmateriale, hvor vi i alt har interviewet 24 medarbejdere, heraf 2 ledere, 11 produktionsmedarbejdere og 11 akademikere. Interviewpersonerne er mellem 30 og 55 år. De arbejder alle i teams og er ansat på fuld tid. Men mens produktionsmedarbejderne arbejder 37 timer om ugen på skiftehold, har de akademiske medarbejdere en arbejdstid, der oftest strækker sig langt ud over en 37 timers arbejdsuge.

Vi har valgt at interviewe medarbejdere fra forskellige afdelinger og teams for at undgå en afdelingsspecifik eller fagligt afgrænset undersøgelse af fællesskabernes liv og betydning i virksomheden. Derfor er interviewpersonernes arbejdsfunktioner og opgaver mangeartede. Alligevel er der nogle generelle træk, der respektivt gør sig gældende for de to medarbejdergrupper.

Produktionsmedarbejderne har alle en håndværksmæssig uddannelse og har i forbindelse med deres ansættelse gennemført et længere oplæringskursus. Et sådant uddannelsesforløb er nødvendigt, fordi produktionen er kompliceret og hovedsageligt computerstyret. Denne medarbejdergruppe bruger det meste af arbejdsdagen i kontrolrum, hvorfra produktionsprocessen kontrolleres via computerskærme, men arbejdet i de selvstyrende teams (grupper) indeholder stadig manuelle elementer såsom udskiftning af ventiler, rengøring og tunge løft. Akademikernes arbejdsopgaver varierer fra primært individuelle opgaver, hvor den enkelte medarbejder indgår i teamet som specialist (f.eks. i patentjura eller kommunikation), til mere kollektive arbejdsopgaver, hvor teamets medlemmer løser kon- krete opgaver i fællesskab (som f.eks. at udtænke nye slogans og marketingsstrategier - eller udvikle tiltag, der kan effektivisere og øge produktionen).

Begge medarbejdergruppers teambaserede arbejdsform er kendetegnet ved en relativt høj grad af selvstyre (medstyre er måske en mere præcis betegnelse, skønt det er selvstyrebegrebet, der anvendes i B A/S), men mens bredden og dybden af akademikernes arbejdsopgaver og deres beslutningskompetence i teamet typisk både er af operationel, taktisk og (sommetider) strategisk karakter, er produktionsmedarbejdernes selvstyreform primært knyttet til det operationelle niveau (Hvenegaard 2003). Trods denne forskel i graden af selvstyre er der tale om, at alle medarbejderne inden for rammerne af nogle fastsatte standarder og mål selv fordeler og planlægger arbejdet i de enkelte teams. Ligeledes koordinerer hvert team selv de interne arbejdsopgaver i forhold til deadlines og de andre samarbejdende teams, ligesom de kan kvalitetssikre, udvikle og forbedre arbejdsprocessen løbende. Desuden har hvert team en tilknyttet leder, der ideelt skal agere som coach frem for at lede, fordele og kontrollere arbejdet på traditionel vis. Lad os efter denne generelle introduktion til undersøgelsens case og dens teambaserede arbejdsformer vende blikket mod projektets analytiske forståelsesramme.

\section{På sporet af B A/S' 'takt og tone' - et analytisk greb}

I B A/S sættes medarbejdernes kontinuerlige udvikling og et udfordrende socialt arbejdsmiljø i højsædet, og virksomheden søger at skabe grobund for selvrealisering såvel som fællesskab blandt medarbejderne. Men det 'væksthus' eller rum for selvrealisering, som virksomheden tilbyder sine medarbejdere, er dog ikke frit og betingelsesløst. Det forudsætter, at de 'realiserer' og 'udfolder sig selv' i overensstemmelse 
med organisationens ledelsesstil, arbejdsform, værdigrundlag og mission. Det implicerer følgelig nogle retningslinjer eller en distinkt 'takt og tone' for, hvorledes medarbejderne skal udfolde deres personlighed. Rummet for selvrealisering kan derfor siges at være indlejret i (og begrænset af) en specifik dannelseskultur, som betinges af den arbejdstakt og omgangstone, der præger måden man omgås (og dannes) på i organisationen - dvs. af en dannelseskultur som både rummer en række 'dannelsestilbud' og 'dannelseskrav'.

I undersøgelsens analysefase har vi induktivt udviklet og anvendt det Emma Gadske begreb 'takt og tone' som en metafor for B A/S dannelseskultur for herved analytisk at kunne skelne mellem 'takten', forstået som den måde der produceres, ledes og arbejdes på, og 'tonen', som udtryk for den daglige og sociale omgangstone og stemning mellem ledere og medarbejdere i virksomheden. Det skal understreges, at dette er en analytisk og forenklet skelnen, eftersom de to aspekter er karakteriseret af en reciprok relation, dvs. at en given arbejdstakt (som f.eks. gruppeorganiseret arbejde i selvstyrende teams) appellerer til en særlig omgangstone (f.eks. en uformel og venskabelig stemning i teamet), og omvendt kan tonen blandt ledere og medarbejdere præge den måde, der ledes og arbejdes på. I praksis udfolder 'takten og tonen' sig derfor i et samspil, der bestemmer omgangsmåden og dannelsesdynamikkerne inden for virksomhedsorganisationen. Vores analytiske skelnen har imidlertid åbnet op for både at undersøge, om og hvorledes B A/S's 'takt' i kraft af den konkrete ledelses- og arbejdsform skaber rum for selvrealisering og fællesskab, og ligeledes om og hvorledes selve den særlige omgangstone og stemning i organisationen skaber grobund for dannelsesprocesser blandt medarbejderne. Dette analytiske greb kan dog ikke alene indfange de konkrete dannelses- dynamikker og socialitetens liv i B A/S, men det favner og udstikker, så at sige, vejen for undersøgelsens tosporede dannelsesperspektiv og operationalisering af fællesskabsbegrebet. Vi vil nu kort redegøre for disse analytiske 'redskaber'.

\section{Samspillet mellem identitet, selvdannelse og fællesskab i et analytisk perspektiv}

Mennesket danner ikke sig selv i et tomrum, men altid i et fællesskab i interaktion/ dialog/ stemthed med andre, som det søger anerkendelse fra. Sagt på en anden måde er vi kun, hvad vi er, i kraft af vores relation til den anden og kun gennem sådanne sociale anerkendelsesrelationer kan vi opnå selvbevidsthed, danne et selv, en identitet og blive personliggjort (Hegel 1996; Wind 1998). Spørgsmålet er, hvordan man mere specifikt kan indkredse og forstå de måder, hvorpå vi selvrealiseres og dannes i det senmoderne arbejdsliv, og de socialitetsformer, der knytter sig hertil?

Vores bud på en besvarelse af dette spørgsmål tager afsæt $\mathrm{i}$ et tosporet dannelsesperspektiv. Det ene spor er identitetsdannelsen (dette perspektiv har sin oprindelse i den kristne selvviden (Foucault 1982)). Ifølge dette perspektiv anskues selvet som konstitueret af viden, og det markerer sig ved fremhævelsen af det erkendelsesorienterede og kommunikative aspekt af selvets praksis. Det er altså her forestillingen, at selvets formning eller dannelse er sprogligt og socialt konstitueret, og at det derfor er i selve artikulationen - når individet artikulerer sin opfattelse af sig selv i dialog med andre - at individet bliver bevidst om sin identitet. Denne forståelse af selvet knytter hermed an til sprogets betydning og betoner, at identitetsdannelsen altid sker inden for en artikuleret socialitet. Med en sådan optik er selvets dannelsesproces betinget af kommunikationsbaserede former for fællesskab, fordi de giver anledning til øget 
selverkendelse og selvviden og derfor indgår som 'råmaterialet' i vores selvfortællinger og selvkonstituerende identitetskonstruktioner (Hammershøj 2003; Foucault 1982; Habermas 1981; Taylor 1989).

Det andet spor er selvdannelsen (dette perspektiv har idehistoriske rødder tilbage til nyhumanismens dannelsesforestilling (Hammershøj 2003)). Her betragtes selvets dannelse som en erfaringsorienteret proces baseret på individets smag for det sociale. Selvet anskues som æstetisk konstitueret af følelsesindtryk, stemningsoplevelser og smagserfaringer, og denne dannelsesform knytter følgelig an til en uartikuleret socialitet, der ikke etableres af en fælles forståelse, men af en fælles stemning eller smagsoplevelse. Det er her tanken, at vi selvoverskrider os i stemningsfællesskabet for at smelte sammen med mængden (at svinge i den samme stemning) - for dernæst at vende tilbage som en særlig personlighed. I kraft af selvoverskridelsen bliver vi altså blot momentant medlem af disse stemnings- eller smagsfællesskaber, som vi vælger på baggrund af vores egen særlige og interessante smag for det sociale. Ifølge denne forestilling fører en konkret smagsdannelse altså til, at man opnår en særlig personlighed, og selvet opfattes i dette lys som 'en smagsafgjort grænse i det sociale'. Vi selvdanner os med andre ord ikke på baggrund af erkendelsesorienterede kommunikationsfællesskaber, men gennem erfaringsbaserede smags- og stemningsoplevelser i og med det sociale (Hammershøj 2003; Schmidt 1999; Simmel 1971).

Det skal pointeres, at disse to perspektiver på nutidens dannelsesprocesser er idealtypiske. Der er tale om en analytisk skelnen mellem to samvirkende processer i selvets konstituering, hvorfor det kan være vanskeligt empirisk at skelne dem fra hinanden. Analytisk er det dog muligt at indfange de to dannelsesformer ved at se på, hvilke former for fællesskab vores identitetskonstruktion og selvdannelse så at sige trækker på. At fokusere på fællesskabernes udtryk, karakter og betydning i B A/S er kort sagt vores 'indgangsnøgle' til at undersøge, hvilken rolle arbejdslivets fællesskaber spiller for medarbejdernes dannelse på jobbet. Et sådant perspektiv adskiller sig fra de mere traditionelle forståelser af begrebet fællesskab, hvor det oftest forankres i en moralsk solidaritet (Durkheim 2000; Juul 2002).

Lad os illustrere, hvorledes vi gennem en skelnen mellem fællesskabernes udtryk som hhv. artikulerede og uartikulerede har forsøgt at operationalisere begrebet fællesskab. De to former for fællesskab kan siges at udgøre en arena for hhv. en erkendelsesog erfaringsbaseret formning af selvet. Men eftersom selvdannelsens uartikulerede socialitetsformer som sagt er karakteriseret af en fælles stemning, omgangstone, eller fornemmelse, foregår denne form for dannelse på et mere subtilt og uartikuleret plan end vores identitetskonstruktioner. Disse er i langt højere grad erkendte og baseret på rationelle og kommunikative fortolkningsfællesskaber. Forenklet kan deres samspil eksemplificeres med, at identitetsdannelsens socialitetsform svarer til de skrevne linier på papiret (hvor betydningen udstanser sig), mens selvdannelsens socialitetsform svarer til det, der står mellem linierne (som mulighedsbaggrund for betydningen). ${ }^{4}$ De fleste fællesskaber indeholder både artikulerede og uartikulerede dimensioner, og de to dannelsesformer (identitetsog selvdannelse) kan således være indlejret i og give anledning til ét og samme fællesskab. I et team kan fællesskabet f.eks. både være karakteriseret ved daglige diskussioner og vidensudveksling, der øger medarbejdernes selvviden (og skaber stof til deres identitetskonstruktion), og samtidig give medarbejderne en fornemmelse eller stemningsoplevelse af samhørighed og af at 'svinge' godt sammen, hvilket øger deres erfaringer med sig selv i og med det sociale 
(og knytter an til selvdannelsesformen) (Hammershøj 2003). Med dette in mente har vi i analysen af fællesskabsformerne i B A/S alligevel primært søgt at tydeliggøre det udtryk (dvs. den grad af artikulation), der er mest karakteristisk for de former for fællesskab, som medarbejderne oplever og trækker på i deres dannelsesprocesser.

Sammenfattende udgør 1) 'takt og tone' metaforen, 2) et tosporet dannelsesperspektiv (identitets- og selvdannelse) - og 3) en skelnen mellem artikulerede og uartikulerede faellesskabsformer vores analytiske ramme for undersøgelsen af samspillet mellem identitet, selvdannelse og fællesskab blandt medarbejderne. Med udgangspunkt i deres subjektive erfaringsunivers(er) vil vi i artiklen eksemplificere, hvorledes vi med denne analytiske optik har forsøgt at nuancere forståelsen af de dannelsesdynamikker og spændingsforhold, der udfolder sig i krydsfeltet mellem B A/S' og medarbejdernes fælles iver efter udvikling og selvrealisering, og de fællesskabsformer, der skabes i kraft hermed.

Inden denne analyse følger dog først en casebeskrivelse, der skitserer den 'takt og tone', som karakteriserer arbejdslivet i virksomheden.

\section{Casebeskrivelse - en skitsering af Bildung $\mathrm{A} / \mathrm{S}$ ' 'takt og tone'}

B A/S lægger i sin ledelsesstrategi vægt på udvikling af de menneskelige ressourcer, hvilket eksemplificeres i deres personalepolitik på følgende måde:

"Vi betragter ikke blot vore medarbejdere som $B$ A/S's mest vaerdifulde aktiv - for os er de selve grundlaget for virksomheden. $B A / S$ prioriterer det højt at skabe spoendende job og tilbyde udviklingsmuligheder i et stimulerende arbejdsmiljø drevet af voerdier «.

Og derfor er det målsætningen, at:
»Vi skal vaere i stand til at tilbyde brede job med større ansvarsområde, der udvikler og udfordrer vores medarbejdere både fagligt og personligt .

Med en fleksibel organisation, værdibaseret ledelse, tilbud om kontinuerlig medarbejderudvikling og teamarbejde søger B A/S at nå en sådan målsætning. Desuden ønsker ledelsen at tage hånd om 'det hele menneske' i kraft af bl.a. personalegoder og fritidstilbud såsom et internt klub-liv, sociale arrangementer, børnehavepasning, firmarabatordninger, hjælp til tøjrens og indkøb m.v. Men hvilken arbejdstakt og omgangstone aftegner sig på baggrund af virksomhedens ledelsesstil og teambaserede arbejdsform? Lad os først se nærmere på selve takten, dvs. på måden der ledes og arbejdes på i organisationen.

\section{Arbejdstakten og omgangstonen}

Ved at lede gennem værdier søger B A/S at involvere medarbejderne og at give dem øget selvbestemmelse eller empowerment, som lederen Lennart udtrykker det. Men sideløbende har ledelsen også implementeret en række styringssystemer, der løbende måler og evaluerer medarbejdernes evne til at leve op til værdigrundlaget - såvel som deres individuelle og fælles præstationer i teamet. I den forbindelse fortæller Lennart, at værdigrundlaget er:

»en pakke som goelder for alle. Ingen slipper for at leve op til det. $O g$ alle bliver $i$ princippet også målt på, at de gør det. " (Lennart, leder)

Værdierne og den dertil knyttede ledelsestakt i B A/S er altså ikke blot et tilbud til medarbejderne om en fælles koordinerende referenceramme for deres handlinger på jobbet, men også noget som de skal identificere sig med og leve op til i deres arbejdsliv. 
Takten i B A/S kendetegnes endvidere af en fleksibel arbejdsorganisering, hvor tværfaglige arbejdsgrupper og teamarbejde medfører, at:

"[medarbejderne] selv skal tage mere ansvar, de skal selv tage initiativ til noget, de skal også uddelegere, de skal loere nye op ... [Fordi] selve teamtanken er ideen om øget selvstyre, eller øget initiativ eller selvorganisering. « (Leif, leder)

Netop fordi teamarbejdsformen appellerer til selvstyre og eget initiativ - eller med andre ord motiverer medarbejderne til selvrealisering - udfordrer og udvikler den ifølge ledelsen medarbejderne, samtidig med at den bidrager til nye praksisformer og fællesskaber gennem f.eks. tværfunktionelle og familiære samarbejdsrelationer i og mellem de enkelte teams. Ledelsen i B A/S fremhæver, at begge disse aspekter er essentielle for et udviklende og stimulerende arbejdsmiljø, og derfor vægter man en arbejdstakt i organisationen, der favner dem begge. Men hvordan opleves disse nye måder at lede og arbejde på af medarbejderne? Begge medarbejdergrupper værdsætter udviklingsmulighederne og den autonomi i arbejdet, som ledelses- og teamarbejdsformen giver mulighed for. Det skaber engagement og 'commitment', og denne effekt udgør en fællesnævner i medarbejdernes beskrivelser af B A/S' arbejdstakt og omgangstone. De knytter bl.a. følgende fortællinger hertil:

"Hun er officielt min chef, men vi deler arbejdet imellem os alt efter, hvad man synes der er sjovt at lave .... Så det er meget meget uformelt og noermest symbiotisk ... og meget venskabeligt ... [Vi har i vores team] en meget toet relation, et meget, meget toet samarbejde, meget teamagtigt. " (Anita, akademiker)

»Det jeg føler her, det er, at der aldrig har voeret forskel på høj og lav, at alle kan snakke med hinanden. " (Phillip, produktionsmedarbejder)

"[Teamarbejdet gør, at man kan] udfolde sig på den måde man er, dvs. man tager ansvaret for det man gerne vil tage ansvar for, og ligesom føler at det er noget man er sammen om.«(Pelle, produktionsmedarbejder)

Særligt det at medarbejderne selv skal tage ansvar og lede sig selv, at lederne agerer som inspiratorer og rådgivere og den uformelle og venskabelige omgangstone i teamet skaber, ifølge medarbejderne, samhørighed og arbejdslyst. Begge medarbejdergrupper fremhæver, at den uformelle ledelsesstil og teambaserede arbejdstakt giver omgangstonen et særligt positivt og venskabeligt præg.

Men tonen og stemningen i de enkelte teams påvirkes også af de personalegoder og sociale tiltag (f.eks. afdelingsseminarer og firmafester), som virksomheden tilbyder medarbejderne. Sådanne tilbud bidrager, ifølge både ledere og medarbejdere, til at skabe stærkere fællesskabsbånd både mellem virksomhed og medarbejder og indbyrdes mellem medarbejderne. At B A/S gennem de sociale arrangementer søger at skabe en unik stemning af at være noget særligt og at tilhøre en udvalgt skare, beskriver en leder på følgende måde:

"... hver gang vi laver et socialt arrangement, så er det $i$ den her ånd ... Der prøver vi også at give en oplevelse af, at det er en fed organisation at vaere $i$, der sker uforudsete ting, der sker maerkelige ting, firmaet vil godt poste penge $i$, at folk har en saerpraeget aften med nogle oplevelser, hvor man indgår i nogle gruppesammenhoeng, e som er usaedvanlige ... og konkurrencer og sådan nogle ting, som er anderledes og moerkelige, og som man bagefter toenker, kan det virkelig ske på mit arbejde, det er sgu da et fedt arbejde ik. «(Leif, leder) 
Igennem de sociale arrangementer og aktiviteter, hvor medarbejderne med deres kolleger i teamet leger, fortæller historier, dyrker sport og bare er sammen for at være sammen, forsøger ledelsen i B A/S således at skabe rum for ekstra arbejdslige oplevelser og stemninger ud over det sædvanlige. Gennem sådanne tiltag tilskyndes medarbejderne til nye fællesskabsdannelser, der rækker ud over det konkrete arbejde og motiverer til både artikulerede og uartikulerede former for socialitet blandt medarbejderne (i og uden for deres arbejdsliv).

\section{Et analytisk blik på dannelsesprocesserne i B A/S}

I analysen vil vi med udgangspunkt i nedenstående spørgsmål indkredse og diskutere de dannelsesdynamikker og spændingsforhold, som B A/S' særlige arbejdstakt og omgangstone giver anledning til blandt medarbejderne:

- Hvilken form, karakter og betydning har fællesskaberne i B A/S, hvordan udfolder de sig, og hvilken rolle har de for medarbejdernes dannelsesdynamikker?

- Hvilke spændingsforhold og menneskelige konsekvenser aktualiserer medarbejdernes dannelsesprocesser i B A/S, og er det kort sagt omkostningsfrit at danne sig på jobbet?

I analysen vil vi sammenholde og undersøge, om der er forskel på de dannelsesstrategier, som hhv. produktionsmedarbejderne og akademikerne trækker på i arbejdslivet.

På baggrund af medarbejdernes fortællinger om deres praksissammenhænge og oplevelser af fællesskab(erne) i arbejdslivet kan man overordnet pege på tre centrale fællesskaber i B A/S; den teambaserede daglige praksis, det faglige liv og det kulturelle liv. Disse tre rum for kollektive praksissam- menhænge skaber hver især grobund for en række forskellige socialitetsformer og fællesskabsdannende potentialer blandt medarbejderne og udgør den tematiseringsramme, hvorudfra vi har indkredset fællesskabernes liv og de dannelsesdynamikker, der knytter sig hertil. Det skal pointeres, at de fællesskabsformer, vi med et sådant analytisk perspektiv har identificeret, naturligvis ikke er udtømmende for den socialitet og de fællesskabsbånd, der kendetegner medarbejdernes arbejdsliv. Imidlertid omfatter perspektivet de fællesskabsformer, der mest typisk fremhæves af medarbejderne i interviewmaterialet, hvorfor det må formodes, at de også tillægges en særlig betydning $\mathrm{i}$ medarbejdernes liv. ${ }^{5}$ Selvom det faglige og kulturelle livs fællesskabsformer i høj grad også præger (og præges af) den teambaserede daglige praksis, vil vi primært rette opmærksomheden mod teamfællesskaberne i B A/S, og de dannelsesprocesser, som de giver anledning til.

\section{Dannelse gennem den teambaserede daglige praksis}

Den daglige praksis' forskellige rum for fællesskab er både artikulerede og uartikulerede i deres udtryk. Især tre specifikke samværsformer blandt medarbejderne udfolder sig inden for dette felt og tager afsæt i hhv. det daglige teamarbejde, teamarbejdets stemning og teamets interaktionsritualer.

For det første tager medarbejdernes daglige teamarbejde form som praksisfællesskaber, der primært knytter an til en kommunikationsbaseret fællesskabsform, hvor medarbejderne gennem artikulation af de konkrete praksissammenhænge både opnår viden om selve arbejdet og en erkendelse af egne og andres evner og dermed 'stof' til deres erkendelsesbaserede identitetsdannelse. Per giver i følgende citat et eksempel på denne form for fællesskab: 
"Vi har nogle gange lidt diskussioner om, hvordan vi skal køre en proces. Så går vi ind og støtter hinanden, når det kører dårligt ... hvis det er noget, der giver problemer, så snakker vi med det hold, som kommer efter os, og så gør vi det sammen.« (Per, produktionsmedarbejder)

At løse arbejdsopgaverne og sammen gøre en god indsats betyder for medarbejderne, at de tilskriver arbejdslivet mening og identificerer sig med fællesskabet. Den daglige teambaserede praksis i B A/S skaber således rum for en artikuleret meningstilskrivelse til arbejdet. Navnlig produktionsmedarbejderne identificerer sig derigennem med teamfællesskabet. Denne forskel mellem de to medarbejdergrupper afspejler sig også ved at akademikerne først og fremmest fremhæver arbejdets selvrealiseringsaspekt som det vigtigste i arbejdslivet, hvorimod produktionsmedarbejderne i højere grad vægter arbejdets fællesskabsaspekt. Dette kan skyldes, at produktionsmedarbejdernes udviklingsmuligheder $\mathrm{i}$ arbejdet er mere begrænsede end akademikernes og at akademikernes arbejdsopgaver i teamet er mere individuelt orienterede og særligt knyttet til den enkelte medarbejders kompetenceområde.

For det andet er læring gennem medarbejdernes praksisfællesskaber også erfaringsbaseret og knytter an til mere uartikulerede former for socialitet. I medarbejdernes teamfællesskaber manifesterer denne uartikulerede dimension af den daglige praksis sig f.eks. i kraft af fælles stemningsoplevelser af synergi og samhørighed, og giver anledning til momentane selvoverskridelser i det sociale, som at grine, joke og føle en fælles stemthed eller arbejdsrytme i teamet. Begge medarbejdergrupper fremhæver denne fællesskabsdimension:

"Vi har sådan en hård [men godmodig] jargon. Det kan jeg godt lide ... Man bliver mere frisk og føler, at man bedre kan snakke med hinanden om forskellige ting." (Pelle, produktionsmedarbejder)

»Vi holder frokost sammen alle sammen, og vi griner helt vildt meget, og vi mobber ufatteligt meget [på en drillende venskabelig måde] ... og det giver altså uhyggeligt meget.«(Anni, akademiker)

Tonen i B A/S styrker ikke blot fællesskabet i teamet og gør arbejdsdagen sjovere, medarbejderne fremhæver også, at teamfællesskabets særlige form og karakter »giver dem utrolig meget « personligt. Gennem sådanne oplevelser danner medarbejderne så at sige smag for det sociale og gør gennem teamfællesskabet erfaringer med sig selv i og med det sociale, hvorfor teamets socialitetsformer også kan siges at knytte an til deres selvdannelse. Dette understreges også af medarbejdernes beskrivelser af teamet som et (uartikuleret) stemningsfællesskab, der er erfaringsbaseret og kropsligt forankret. Eksempelvis fortæller Piet, at grunden til at han godt kan lide at arbejde i team, er: »fordi vi svinger udmoerket sammen " (Piet, produktionsmedarbejder). Sådanne oplevelser af samhørighed kan i et analytisk perspektiv ses som eksempler på medarbejdernes momentane selvoverskridelser i det sociale, fordi de gennem disse former for fællesskab oplever en periodisk 'sammensmeltning' med kollegerne i teamet (at være et 'vi', når der arbejdes, festes eller når medarbejderne omsluttes af den samme humor). Det fællesskab, der konstitueres omkring medarbejdernes respektive teams, forudsætter dog, at man kan ramme den rigtige tone og jargon. Og det stiller store personlige og følelsesmæssige krav til den enkelte.

For det tredje er den teambaserede daglige praksis kendetegnet ved at indeholde forskellige 'rituelle handlinger', der kan betragtes som en særlig socialitetsform. Eksempelvis mødes nogle teams hver dag 
klokken tre og drikker kaffe, mens andre har ritualer i forbindelse med frokosten, eller når de møder på arbejde. Sådanne rituelle interaktioner kræver medarbejdernes fulde opmærksomhed, og at de er i samme humør eller sindsstemning. Disse forhold eller 'emotionelle ingredienser', som Randall Collins betegner det, skaber en særlig rytme i teamet, der er med til at generere ritualets resultat, som er en følelse af solidaritet blandt medarbejderne i teamet (Collins 1990). Per fortæller i følgende citat om de 'emotionelle ingredienser' i et af produktionsmedarbejdernes daglige ritualer og om, hvorledes han oplever, at medarbejderne i teamet støtter hinanden gennem denne rituelle handling (anerkendelse):

»Det giver den tilfredsstillelse, når man kan se, at folk er glade ... når vi møder om morgenen [i teamet], så giver vi altid hinanden hånden. Det har vi bare holdt fast ved, og det er bare en god lille ting, når man kommer ind ad døren om morgenen - så giver man hinanden hånden og siger godmorgen. Det giver en god stemning. " (Per, produktionsmedarbejder)

Interaktionsritualerne har således en anerkendende funktion, hvilket netop er forudsætningen for deres dannelsespraktikker. Af citatet fremgår det, at Per oplever ritualet som »en god lille ting «, der skaber glæde og fælles stemthed. Ligeledes fortæller akademikeren Andreas, hvorledes fejringer af teamets resultater, f.eks. med 'hurraråb' på gangene, betyder, at medarbejderne får en fælles oplevelse af styrke, som reflekterer tilbage på den enkelte.

Sammenfattende tyder det på, at den daglige teambaserede praksis, dens stemninger og interaktionsritualer skaber forskellige artikulerede og uartikulerede socialitetsformer, der giver anledning til både identitets- og selvdannelsesprocesser blandt begge medarbejdergrupper. Vores analyse peger imidlertid også på, at produktionsmedarbejdernes dannelsesdynamikker i langt højere grad end akademikernes knytter sig til det daglige liv i produktionen og de praksisfællesskaber, som de indgår i med kollegerne. Det kan både skyldes arbejdsopgavernes mere kollektive organisering - og at deres faglige udviklingstilbud er mere begrænsede end akademikernes.

I det følgende vil vi illustrere, hvorledes også det faglige og kulturelle liv aktualiserer en række dannelsesdynamikker blandt medarbejderne.

\section{Dannelse gennem det faglige liv}

Det faglige liv kan anskues som en overordnet socialitetsform blandt medarbejderne, idet det skaber rum for samværsformer og kollektive praksissammenhænge, såsom efteruddannelse, konferencer, faglige netværk, udviklingssamtaler, evalueringer m.v. De rummer alle et eksplicit formål om medarbejderudvikling og kan betragtes som erkendelsesorienterede (og artikulerede) fællesskaber, der bidrager til medarbejdernes identitetskonstruktioner. Navnlig selvudviklingskurserne og medarbejdernes refleksive selvpraksisser aktualiseres i takt med virksomhedernes øgede fokus på de menneskelige ressourcer og sociale kompetencer $\mathrm{i}$ arbejdslivet.

Blandt produktionsmedarbejderne skaber de faglige samværsformer grobund for etableringen af nære sociale og venskabelige bånd, der rækker ud over selve arbejdssfæren. Det står i kontrast til akademikernes mere nytteorienterede fællesskabsrelationer. Peter fortæller i følgende citat om dette aspekt af produktionsmedarbejdernes faglige liv:

"Altså dér på skolen, jamen ved du hvad, når vi er foerdige, så skal vi sgu' have en fest og så ud at spise og så hjem og hygge og alt sådan noget rent spontant. «(Peter, produktionsmedarbejder) 
De akademiske medarbejdere fremhæver derimod, at det faglige liv primært giver dem mulighed for at skabe deres egne uformelle faglige netværk i organisationen, og at disse netværk mere har karakter af nytteorienterede 'noget for noget' relationer. Det faglige liv muliggør en form for 'relationssolidaritet' (Bering 2003) med erkendelsesbaserede anerkendelsesrelationer, som rækker ud over deres specifikke afdelinger og konkrete kursusaktiviteter (Enemark \& Lotz 2003, 136-138).

En anden forskel mellem de to medarbejdergrupper er, at produktionsmedarbejderne ikke tilbydes selvudviklingskurser; det er primært en dannelsesstrategi for akademikerne. Alligevel oplever begge faggrupper, at de gennem arbejdet udvikles både fagligt og personligt, og at virksomhedens udviklingssamtaler og evalueringssystemer i høj grad er med til at fremme denne udviklingsproces.

\section{Dannelse gennem det kulturelle liv}

Det er dog især i kraft af B A/S' kulturelle liv og dets uartikulerede former for socialitet at medarbejdernes selvdannelsesdynamikker udfolder sig. Selvom værdifællesskaberne og de ekstra arbejdslige fællesskaber på den ene side er at betragte som nye former for kommunikationsfællesskaber i arbejdslivet, så fremgår det på den anden side af medarbejdernes fortællinger, at de i høj grad også aktualiserer en række nye former for uartikuleret socialitet, der skaber rum for en mere smags- og stemningsbaseret formning af selvet på jobbet. Blandt andet udspiller værdifællesskaberne i $\mathrm{B} \mathrm{A} / \mathrm{S}$ sig også på et mere ubestemt og uartikuleret plan, som en fælles stemthed eller fornemmelse blandt medarbejderne. F.eks. fortæller Aksel, at:

"[Voerdigrundlaget] er en naturlig del af det, at vi er flasket op med det, og sådan virker det bare. Man toenker egentlig ikke på det." (Aksel, akademiker)
Denne selvfølgelige oplevelse af værdigrundlaget understreges af, at medarbejderne ikke opfatter værdigrundlaget, som noget 'der kommer udefra' eller som et arbejdsredskab, men snarere som en beskrivelse af, hvordan de alle sammen er. I B A/S kan man sige, at medarbejderne i høj grad danner smag for at efterligne B A/S' personlighed (eller vælger B A/S som deres forbillede) med henblik på at blive noget særligt. Eksempelvis forklarer akademikeren Anders, hvorledes virksomhedens 'karaktertræk' 'smitter af' på hans egne, og at det derfor er vigtigt for ham at arbejde et sted med 'gode' værdier. Det lader således til, at B A/S har formået at 'indkode' virksomhedens personlighed i deres medarbejdere, der ikke oplever dette 'dannelsestilbud' som indoktrinerende eller begrænsende, men snarere som en naturlig sammensmeltning af deres egen og virksomhedens personlighed.

De sociale arrangementer, afdelingsseminarer og øvrige ekstra-arbejdslige sociale tiltag knytter også an til uartikulerede socialitetsformer i arbejdslivet. ${ }^{6}$ For eksempel fremhæver Pede, at det essentielle ved deres afdelingsseminarer er, at de bidrager til en oplevelse af 'selskabelighed' (Simmel 1971):

»De dér seminarer ... det er noesten lige meget, hvad man laver, bare det at voere sammen, det betyder også meget ... bare det at man sidder og snakker med de andre, det betyder meget. " (Pede, produktionsmedarbejder)

Målet med denne fællesskabsform er med andre ord, ifølge Pede, selve fællesskabet, og ved at selvoverskride sig i sådanne stemningsfællesskaber lader det til at medarbejderne oplever et momentant medlemskab, når de erfarer at svinge i den samme selskabelige stemning. Et andet eksempel giver Anna, der sammen med sine teamkolleger på et seminar har slugt ild og slået brædder 
over med flad hånd. Det bidrog til en fælles oplevelse af styrke i gruppen og en stemthed over at kunne mere, end man troede. En sådan fælles stemningsoplevelse kan siges at skabe grobund for en erfaringsdannelse blandt medarbejderne for den 'interessante smag' (i dette tilfælde er at sluge ild og afprøve nye grænser). I kraft af denne fælles smags- og stemningsoplevelse kan medarbejderne erfare at blive noget særligt. Således bekræfter vores analyse at momentane former for selvoverskridelse på baggrund af personlig efterligning, oplevelsen af at svinge i den samme stemning eller smagsafgrænsninger for det interessante $\mathrm{i}$ udpræget grad er karakteristisk for medarbejdernes erfaringer med det kulturelle livs uartikulerede smags- og stemningsbaserede former for fællesskab i B A/S.

En forskel mellem de to medarbejdergrupper kobler sig dog til det kulturelle livs socialitetsformer. For blandt produktionsmedarbejderne er det selve selskabeligheden frem for samværsformernes konkrete og interessante indhold, der har primat i relation til afdelingsseminarerne og de sociale arrangementer. Hvorimod disse socialitetsformers konkrete aktiviteter i højere grad skaber grobund for erfaringsdannelser for den interessante smag og særlige stemningsoplevelser blandt akademikerne. Denne forskel afspejler to forskellige dannelsesdynamikker mellem grupperne, idet produktionsmedarbejderne gennem selskabeligheden bliver beriget og noget særligt i kraft af det blotte samvær med kollegerne, hvorimod akademikernes stemningsfællesskaber i højere grad bruges som en arena for deres søgen efter den interessante smag eller stemningsoplevelse, og dermed som afsæt for at danne et særligt smagsafgjort selv.

Uanset disse forskelle konkluderes sammenfattende, at begge medarbejdergrupper er indlejret i og trækker på både artikulerede og uartikulerede socialitetsformer i deres arbejdsliv og at disse fællesskaber indgår som et vigtigt led i deres dannelsesprocesser - og giver anledning til en lang række af dannelsesdynamikker på jobbet.

\section{Dannelsens pris på jobbet med fokus på teamarbejdets spændingsforhold og menneskelige konsekvenser}

På baggrund af medarbejdernes erfaringsverden tegner der sig en række spændingsforhold, der på hver sin måde sætter fokus på dannelsens negative konsekvenser og de skyggesider, som nutidens udviklende teamdynamikker og øvrige socialitetsformer i arbejdslivet også fører med sig.

Kontinuerlig læring og opnåelse af en høj grad af faglig kunnen er ikke kun et ønske blandt medarbejderne og et tilbud i B A/S, men også et krav både fra virksomhedens side og et krav mellem medarbejderne indbyrdes. Pelle ekspliciterer det 'kollegiale' krav om kvalifikationsoptimering således:

»... Der er et indbyrdes krav om, at man skal udvikle sig, man skal kunne mere og mere, fordi det hjoelper os alle sammen." (Pelle, produktionsmedarbejder)

Et krav om til stadighed at ville og kunne opkvalificere sig er således en del af medarbejdernes virkelighed. At denne 'udviklingstvang' kan resultere i et arbejdsfællesskab, der kun er rummeligt for de stærke, effektive og udviklingsparate medarbejdere, er en skyggeside ved B A/S' teambaserede arbejdsform, som seniorerne i B A/S meget direkte italesætter og problematiserer. En anden skyggeside ved et udviklende teamfællesskab er, at virksomhedens og medarbejdernes fælles 'udviklingsiver' kan resultere i arbejdslivets dominans. Mens produktionsmedarbejderne oplever et skarpt skel mellem arbejdsliv og privatliv, knytter der sig i den forbindelse nogle spændingsforhold til akademikernes arbejdsiver og forhold til deres arbejdstid, eftersom denne medarbejdergruppe oplever, 
at arbejdslivets dominans både tidsmæssigt og mentalt ofte er prisen for et engagerende og udviklende arbejdsliv. Annas nedenstående citat antyder disse risici ved udviklingsiveren i B A/S:

"... nu klistrer vi små moerker på vores computere, hvor der står, at man skal huske at troekke vejret engang imellem, for det er altså vigtigt ikke. Eller vi har nogle andre små moerker, hvor der står, at man skal loegge sig ned på gulvet og lave yogaøvelser $i$ 5 minutter, eller at man har en lille brik på sit rat, når man kører hjem, der også siger én, at nu skal man gøre sådan og sådan." (Anna, akademiker)

Annas behov for ovenstående påmindelser indikerer i hvert fald, at den fælles 'takt og tone' i B A/S kan rumme en slagside, idet hendes selv og velbefindende så at sige domineres af en opslugende arbejdsiver og et (selvvalgt?) arbejdspres.

Desuden medfører teamarbejdet en øget gensidig afhængighed og kontrol medarbejderne imellem, hvilket uundgåeligt implicerer en række spændingsforhold. Teamarbejdsformen rummer f.eks. et ambivalent forhold til konkurrence - for selvom der lægges vægt på at 'løfte i flok', så evalueres og belønnes medarbejderne også i forhold til deres individuelle præstationer. Dette spændingsforhold indfanger Andreas således:

»arbejdet er tilrettelagt på en sådan måde, at man ikke 'hyper' den enkeltes prostation, udover en gang om året når bonusen skal deles rundt.« (Andreas, akademiker)

Trods en stærk team ånd er konkurrencemomentet altså alligevel tilstede blandt de ansatte. Åbenlys konkurrenceadfærd er dog ikke velset, og implicit i teamarbejdsformen ligger et lighedsideal, som løbende fremhæves af både ledere og ansatte i B
A/S. ${ }^{7}$ Dette ideal betyder, at medarbejderne ikke åbenlyst må udtrykke (eller føle) overeller underlegenhed over for kollegerne, til trods for at de konkurrerer om de samme bonusudbetalinger og forfremmelser. Når medarbejderne danner sig i kraft af teamfællesskabet, internaliserer de således også nogle selvrestriktioner og følelsesmæssige regler for, hvorledes de skal handle og være. Eksempelvis fremhæver medarbejderne, at man altid skal være positiv, at det ikke er 'god tone' at udtrykke negative følelser, at være vred eller kritisere virksomheden, og at der, med Anjas ord, ikke er plads til brokkerøve og burnouts i teamfællesskabet. Et af problemerne med en sådan 'nicenesskultur' er, at den vanskeliggør, at konflikter ekspliciteres og behandles i åbenhed.

Et tredje spændingsforhold knytter sig til B A/S' ledelse (magtudøvelse), der handler om medarbejdernes aktive selvledelse. Teamarbejdsformen er nemlig ikke ensbetydende med en svækkelse af ledelsens indflydelse - snarere tværtimod, idet ledelsens krav og forventninger hermed bliver internaliseret i medarbejderne, der leder og kontrollerer sig selv og hinanden i teamet indenfor ledelsens fastsatte rammer. Selvom der er tale om en frivillig og aktiv selvsocialisering til selvledelse (dannelse), har magtens decentralisering alligevel menneskelige konsekvenser. Ansvaret for arbejdsforholdene, de lange arbejdsdage (blandt akademikerne) og de interne problemer i teamet føres nemlig, qua denne selvledelse, tilbage til den enkelte medarbejder. Problematikker i arbejdslivet opfattes hermed ikke som ledelsens eller 'systemets' ansvar, men som den enkelte medarbejders ansvar og personlige hovedpine.

Medarbejderne i B A/S har dog øje for denne skyggeside af magtens decentralisering. F.eks. fortæller Palle om en medarbejder, der ikke er i stand til at arbejde som de andre i teamet, hvorfor hans kolleger må overtage hans nattevagter: 
»Vi har en på vores hold, som er fritaget for nattevagt $i$ øjeblikket, men kun $i$ kraft af at der er to kolleger ... der vil gå ind og tage hans nattevagter. Det er ikke i kraft af, at firmaet gør noget." (Palle, produktionsmedarbejder)

I et sådant perspektiv er medarbejdernes dannelsesdynamikker på jobbet ikke omkostningsfrie, eftersom magtens usynliggørelse i B A/S kamuflerer det reelle konfliktforhold mellem leder og medarbejder og subjektiverer og disciplinerer medarbejderne til selvledelse, hvorfor oplevede spændingsforhold og konflikter bliver et personligt problem og ansvar. Analogt bekræftes denne konsekvens i bl.a. Tynell og Caseys empiriske undersøgelser af de nye ledelsesog arbejdsformer (Tynell 2001; Casey 1995).

Et fjerde spændingsforhold kobler sig til teamfællesskabets eksklusionsmekanismer i form af krav til medarbejderne om, at de skal være funktionsduelige, effektive og som sagt udviklingsparate. Hvis der f.eks. er et 'svagt led' i teamet, skal de øvrige medarbejdere være desto stærkere og hurtigere for at løfte arbejdsbyrden. Peter beskriver denne situation:

»hvis du har nogle kolleger, der er meget syge, hvor de andre kolleger skal løbe noget stoerkere $i$ arbejdsdagen ... så kan man sådan også blive lidt arbejdspresset. «(Peter, produktionsmedarbejder)

På grund af medarbejdernes selvledelse er det teamets eget problem at tackle sådanne situationer. Det øger arbejdspresset og den gensidige afhængighed, og det kan resultere i, at man i teamet vender sig imod dem, som ikke kan 'levere varen' (Casey 1995). Dette eksemplificeres bl.a. ved, at begge medarbejdergrupper understreger, at det er ok at have en dårlig dag, så længe der kun er få af slagsen. En af skyggesiderne ved de selvstyrende teams er således, at fællesska- bet kan presse eller måske ekskludere de medarbejdere, som ikke er 100\% funktionsduelige og effektive.

Således skaber B A/S' teambaserede daglige praksis ikke blot grobund for udviklende dannelsesdynamikker, men også for menneskelige konsekvenser og spændingsforhold blandt medarbejderne.

Opsummerende peger analysen på, at arbejdslivets fællesskabsformer og teamdynamikker har deres omkostninger. De kan resultere i arbejdslivets dominans, en usynliggørelse af magtrelationer, en tabuisering af konfliktforhold, en adfærdsregulerende og begrænsende følelseskultur og et fællesskab for kun de udviklingsparate, ressourcestærke og effektive medarbejdere med et tilpasningsdygtigt selv. Ligeledes er det vigtigt ikke at være blind for, at B A/S' socialitetsformer (såsom f.eks. teamet) er designede til at skabe mere 'committede', engagerede og dermed effektive medarbejdere og således er betinget af virksomhedens økonomiske rationale. De er i dette lys først og fremmest et middel til $\mathrm{B} \mathrm{A} / \mathrm{S}^{\prime}$ mål om bedre konkurrenceevne og profit. Dette er naturligvis et uomgængeligt vilkår for virksomhedens eksistens og virke, som dog let kan fortone sig i B A/S' uformelle og familiære 'takt og tone', positive retorik om udviklingen af hele mennesker og den fælles 'udviklingsiver'. Vi mener derfor, at det er vigtigt at have øje for, at de fællesskaber, der initieres af virksomheden og udfolder sig indenfor disse organisatoriske rammer, ikke er spontane og baseret på medarbejdernes eget initiativ. I en amerikansk kontekst har bl.a. Casey og Hochschild peget på denne problematik, og vores analyse viser, at den i dag også gør sig gældende på dansk jord.

\section{Afrunding}

Vi har i denne artikel sat fokus på samspillet mellem selvrealisering og fællesskab blandt medarbejderne i en casevirksom- 
hed, (B A/S ) - og dermed skitseret 'takten og tonen' i B A/S, de dannelsesprocesser og dynamikker, den skaber grobund for i synergi med medarbejdernes selvrealiseringsiver - samt nogle af de konsekvenser, dannelse på jobbet fører med sig.

Hermed har vi illustreret, at medarbejdernes 'selvrealiseringsiver' og dannelsesprocesser ikke sker på trods af fællesskabet, men i kraft heraf, og derfor giver anledning til en række nye artikulerede såvel som uartikulerede socialitetsformer i arbejdslivet. Særligt teamarbejdsformens 'rum' for kollektive praksissammenhænge giver anledning til både identitets- og selvdannelse blandt medarbejderne i B A/S, idet den daglige teambaserede praksis, dens stemninger og interaktionsritualer åbner op for anerkendelse, samhørighed, ansvar og personlig udvikling blandt medarbejderne. Også det faglige og det kulturelle liv i B A/S aktualiserer en række dannelsesdynamikker blandt medarbejderne og giver både 'stof' til medarbejdernes identitskonstruktioner og en mere smags- og stemningsbaseret formning af selvet.

Der tegner sig samtidig karakteristiske forskelle mellem de to grupper af ansatte: Forskellen mellem de to medarbejdergrupper afspejler sig bl.a. ved, at produktionsmedarbejdernes dannelsesdynamikker i langt højere grad knytter sig til det daglige liv i produktionen og de praksisfællesskaber, som de indgår i med kollegerne i deres respektive teams. En af årsagerne til dette kan være, at produktionsmedarbejdernes udviklingsmuligheder i arbejdet er mere begrænsede end akademikernes, hvis arbejdsopgaver i højere grad er knyttet til den enkelte medarbejders kompetenceområde. I forbindelse med det faglige liv tegner der sig også en markant forskel. Blandt produktionsmedarbejderne skaber de faglige samværsformer grobund for nære og sociale venskabelige bånd, der rækker ud over selve arbejdssfæren, hvilket står i kontrast til de mere nytteorienterede fællesskabsrelationer, som akademikernes faglige liv aktualiserer. Desuden knytter medarbejdernes erfaringer med det kulturelle liv an til to forskellige dannelsesdynamikker, idet produktionsmedarbejderne primært danner sig i kraft af det blotte samvær med kollegerne, hvorimod akademikerne i højere grad vægter samværsformernes konkrete indhold, som afsæt for at danne et særligt smagsafgjort selv.

Afslutningsvis har vi også kritiseret teamfællesskaberne i B A/S og problematiseret det liv, de giver anledning til blandt medarbejderne. De fortrænger interesseforskelle og konflikter mellem leder og medarbejder, er snævert designede til virksomhedens værdier, strategi og mål - og rummer et eksklusionsmoment, der favoriserer bestemte karaktertræk (såsom udviklingsparathed, 'committment', funktionsduelighed og 'positive' følelser), og begrænser rummet for mangfoldighed.

Som vi ser det, er det derfor vigtigt at medtænke, italesætte (og yderligere udforske) disse skyggesider af nutidens fællesskabsdannelser på jobbet, som går hånd $\mathrm{i}$ hånd med medarbejdernes selvrealiseringsiver og de senmoderne dannelsesdynamikker i arbejdslivet. For kun i kraft af et sådant kritisk blik kan et øget refleksionsniveau om både de positive dimensioner såvel som de negative konsekvenser ved udviklingstendenserne $\mathrm{i}$ vores arbejdsliv etableres blandt virksomhedsledere, medarbejdere, fagforeninger og arbejdslivsforskere. En sådan fælles og bred italesættelse er, for os at se, en afgørende forudsætning for et udviklende arbejdsliv med rum for mangfoldige dannelsesdynamikker og rummelige (team)fællesskaber. 


\section{NOTER}

1. Casestudiet er gennemført i 2003 som led i forfatternes specialeprojekt Dannelse og foellesskab i nutidens arbejdsliv ved Sociologisk Institut, Københavns Universitet. En version af specialet findes på Sociologisk Instituts bibliotek.

2. Selve vores problemstilling lægger derfor op til metoder og datatyper med et forståelsesorienteret og fortolkende perspektiv. Vi henviser til specialets metodiske passager for en uddybning af vores multimetodologiske approach og videnskabsteoretiske afsæt.

3. Dette strategiske valg af en casevirksomhed, der er frontløber med hensyn til nye udviklingstendenser i arbejdslivet, sigter på det gode eksempels magt - og dermed et mere generaliserende indblik i dannelsesdynamikker og skyggesider i nutidens arbejdsliv (Flyvbjerg 1991; Yin 1984).

4. (Hammershøj 2003, 210-211). Skriftbilledet (linierne og mellem linierne) er vores egen billedliggørelse af samspillet mellem de to socialitetsformer.

5. Fagforeninger og faglige klubber kan siges at repræsentere solidaritetens institutionaliserede udtryk, men ikke nødvendigvis det levede fællesskab på arbejdspladsen, som er denne undersøgelses genstandsfelt. Ingen af vores informanter har bragt disse faglige fællesskaber på banen i forbindelse med deres beskri- velser af fællesskabernes liv og betydning i B $\mathrm{A} / \mathrm{S}$, hvorfor deres rolle i arbejdslivet ikke vil blive diskuteret yderligere i denne artikel.

6. Afdelingsseminarerne og de sociale arrangementer i B A/S kan naturligvis også betragtes som kommunikationsfællesskaber, hvor medarbejderne erhverver viden om hinanden som en gruppe og en erkendelse af, hvor de selv passer ind. I kraft af disse fællesskaber oplever medarbejderne et tilhørsforhold til deres team og afdeling. De fremhæver, at disse ekstra-arbejdslige samværsformer og fora for dialog er med til at fremme 'vi' følelsen i organisationen.

7. I undersøgelsens interviewmateriale er konkurrencemomentet underbelyst - til trods for vores mange spørgsmål til denne tematik »Det [konkurrence] er jo skjult, for det er ikke noget vi går og snakker om sådan generelt, men man kommer jo med stikpiller til de andre " fortæller produktionsmedarbejderen Pelle. Akademikeren Allan understreger en lignende tendens: "Jo selvfølgelig vurderer vi hinandens arbejde. Men det er jo ikke altid, at vi snakker om det ...«. Andre undersøgelser peger ligeledes på konkurrenceelementet i nutidens teamfællesskaber, men at elementet tabuiseres, fordi teamarbejdsformen bygger på en forestilling om, at alle er lige (se f.eks. Sennett 1999, Bloch 2002, Tynell 2001).

\section{RefERENCER}

Abrahamson, Peter (2002): Anmeldelse af Sørens Juuls: Modernitet, velfærd og solidaritet, i Dansk Sociologi, 13, 4, 109-111.

Aveneri, Shlomo (1972): Hegel's Theory of the Modern State, Cambridge, Cambridge University Press.

Beck, Ulrich \& Elisabeth Beck-Gernsheim (2002): Individualization - Institutionalized Individualism and its Social and Political Consequences, London, Sage Publications.

Bering, Ida (2002): Når det dårlige arbejde også er godt, ph.d.-afhandling, Roskilde Universitetscenter.
Bloch, Charlotte (2002): Følelser og sociale bånd i Akademia, i Dansk Sociologi, 13, 4, 4361.

Bovbjerg, Kirsten (2003): Arbejdsliv uden grænser - Belastende fokus på medarbejderens personlighed, i Tidsskrift for Arbejdsmiljø, 5, 1, 23-24.

Casey, Catherine (1995): Work, Self and Society after industrialism, London, Routledge.

Clark, Candace (1990): Emotions and Micropolitics i Everyday Life - Some Patterns and Paradoxes of 'Place', i Theodore D. Kemper (red.): Research Agendas in the Sociology of 
Emotions, New York, State University of New York Press, 305-333.

Collins, Radall (1990): Stratification, Emotional Energy and the Transient Emotions, i Theodore D. Kemper (red.): Research Agendas in the Sociology of Emotions, New York, State University of New York Press, 27-57.

Csonka, Agi (2000): Ledelse og arbejde under forandring - Om indholdet, udbredelsen og konsekvenserne af fleksible organisationsformer i danske virksomheder, København, Socialforskningsinstituttet.

Durkheim, Émile (2000): Om den sociale arbejdsdeling, København, Hans Reitzels Forlag.

Enemark Olsen, Signe \& Maja Marie Lotz (2004): Dannelse og foellesskab i nutidens arbejdsliv, Specialeserien, Sociologisk Institut, Københavns Universitet.

Flyvbjerg, Bent (1991): Rationalitet og magt, Bind 1 - Det konkretes videnskab, København, Akademisk Forlag.

Foucault, Michel (1982): Technologies of the Self, i Paul Rabinow (red.): Ethics, London, Allen Lane, 223-251.

Habermas, Jürgen (1981): Teorien om den kommunikative handlen, Aalborg, Aalborg Universitetsforlag.

Halkier, Bente (2002): Fokusgrupper, København, Samfundslitteratur \& Roskilde Universitetsforlag.

Hammershøj, Lars Geer (2001): Selvdannelse og nye former for socialitet - technofesten som eksempel, i Dansk Sociologi, 12, 2, 23-43.

Hammershøj, Lars Geer (2003): Selvdannelse og socialitet - Fors $\emptyset g$ på en konstruktivistisk orienteret socialanalystisk samtidsanalyse, ph.d.-serien, Sociologisk Institut, Københavns Universitet.

Hegel, G.W. (1996): Hegel - De store tænkere, København, Munksgaard.

Herman, Stefan (2003): Fra styring til ledelse om kompetencebegrebets udvikling, i Tidsskriftet Uddannelse, 03, 01, 1-7.

Herman, Stefan (2000): Fra magt/viden og dominans til selvteknologier og frihedspraksis - Sociologiske troek af Michel Foucaults samtidsdiagnose, Institut for Statskundskab, Århus Universitet.
Hvenegaard, Hans, Helge Jessen \& Peter Hasle (2003): Gruppeorganiseret arbejde - På vej mod bedre arbejdsmiljø og konkurrenceevne?, København, Frydenlund.

Juul, Søren (2002): Modernitet, velfoerd og solidaritet - En undersøgelse af danskernes moralske forpligtelser, København, Hans Reitzels Forlag. Kristensen, Jens Erik (2001): Den urene økonomiske fornuft, i Jens Erik Kristensen \& Carsten Fenger-Grøn (red.): Kritik af den økonomiske fornuft - en antologi, København, Hans Reitzels Forlag, 217-247.

Nielsen, Kurt Aagaard (1990): Arbejde - Lyst eller nød, i Peter Gundelach, Nils Mortensen \& Jens Chr. Tonboe (red.): Sociologi under forandring, København, Gyldendal, 225-248.

Schmidt, Lars-Henrik (1999A): Utraditionel dannelse, i Diagnosis III, København, Danmarks Pædagogiske Universitet.

Schmidt, Lars-Henrik (1999B): Dannelse på ny og Dannelse og almendannelse, i Diagnosis I, København, Danmarks Pædagogiske Universitet.

Sennett, Richard (1999): Det fleksible menneske eller arbejdets forvandling og personlighedens nedsmeltning, Højbjerg, Forlaget Hovedland.

Simmel, Georg (1971): On Individuality and Social Forms, Chicago, The University of Chicago Press.

Taylor, Charles (1989): Sources of the Self - The making of the Modern Identity, New York, New York University Press.

Tynell, Jesper (2001): Da medarbejderne blev en ressource - Magtrelationer i en virksomhed, der profilerer sig på at pleje og udvikle medarbejdernes ressourcer, Specialeafhandling, Roskilde, Roskilde Universitetscenter.

Wenger, Etienne (2002): Communities of Practice - Learning, Meaning and Identity, Cambridge, Cambridge University Press.

Wind, H.C. (1998): Anerkendelse - Et tema i Hegels og moderne filosofi, Aarhus, Aarhus Universitetsforlag.

Yin, Robert K. (1984): Case Study Research - Designs and Methods, Thousands Oaks, Sage Publications Inc. 
Maja Marie Lotz, cand. scient. soc., ph.d.studerende ved Institut for Organisation og Arbejdssociologi/International Center for Business and Politics, (CBS). ml.cbp@cbs.dk
Signe Enemark Olsen, cand. scient. soc., ansat som personalekonsulent i Helsingør Kommune.

Soll2@helsingor.dk 